Fernando Santiván

\title{
EL PRIMER IMPULSO
}

\section{(DE LAS MEMORIAS DE UN TOLSTOYANO)}

RAMOS tres. Nada más que tres. La historia ha falseado más tarde el hecho, como ha falseado otros de mayor importancia.

Thomson pontificaba. Nació destinado para ejercer de pontífice o de actor, que es la misma cosa.

- He torcido mi destino,-solía repetir.

Y recordaba que, siendo un tierno infante, pasó por nuestra menguada metrópoli una compañía de cómicos, presidida por un actor llamado Galé. Augusto asistió por primera vez a una representación de Tierra Baja, de Guimerá. Tuvo un deslumbramiento. Y pocos días más tarde presentóse al alojamiento de Galé para pedirle que lo incorporáse a su farándula. El viejo actor sonrió:

- ¿Tiene usted condiciones?

-Póngalas a prueba-exclamó el niño con arrogancia.

-Recíteme algo...

$Y$ sin esperar más, Augusto revolvió con las manos su encrespada melena; se ató la frente con un pañuelo, quitóse el paltó, desabrochóse el cuello de la camisa, y, ya en carácter, saltó sobre una vieja mesa dispuesto a declamar el monólogo de Manelik, aquel que ha sido el escollo máximo de los trágicos españoles. 
Desarrollóse la maravilla. El viejo actor cavilaba. Tierra Baja hacía su estreno en Chile; Galé era el portador de la primicia, y sólo habíala puesto en escena dos veces. ¿Cómo pudo copiar el monólogo aquel muchacho de ojos obscuros hundidos en cavernas de sombra? iY aquella voz limpia, con sonoridades de plata y de bronce, que enronquecía y enturbiaba adrede para simular los rugidos de la fiera! El viejo actor cavilaba.

- ¿En dónde aprendió ese monólogo?-interrogó, el actor, desconfiado.

- ¡De oírlo a usted!-respondió el muchacho. Tiene, pues, una memoria prodigiosa...

Dícenlo así...

Está bien. Será usted un gran actor. Sólo espero el consentimiento de su familia, para llevarlo conmigo... Dentro de dos días saldré de Chile.

Aquel proyecto no pudo realizarse. El viejo primo Manuel, pintor de mérito que ejercía gran influjo sobre el muchacho artista, se encargó de disuadirlo. Era más noble la carrera de escritor, y menos arriesgada para una joven naturaleza. $Y$ así fué como el arte perdió un émulo de Borrás, de Tallaví o de Talma.

Pero si Augusto no fué actor de teatro, siguió siéndolo en la vida. Se rodeaba de una liturgia de artista romántico, y obligaba a los suyos a que actuaran de acuerdo con sus dorados sueños. Sus jóvenes hermanas debían reverenciarlo. En el hogar modesto había establecido rituales que, en grado ínfimo, recordaba el ceremonial de Luis XIV, el rey sol.

En cierta ocasión se declaró inventor de un idioma nuevo, tan arbitrario como pintoresco. Las hermanas y la vieja abuela debieron emprender el estudio de una gramática, intrincada como selva austral.

- ¿Garrapatatis trumbum almidonis?

Aquella interrogación significaba, simplemente, si 
habrían traído las camisas de donde la lavandera; pero como las muchachas no lo entendiesen, el niño Augusto montaba en su caballo diabólico y hacía restallar el látigo de insultos feroces.

Es indudable que el carácter dominante del jovenzuelo adquirió un desarrollo extraordinario, debido a la bondad inagotable de la abuela, que lo adoraba.

La anciana señora arrastraba con seráfica sencillez, los últimos resplandores de una gran belleza.

-Es mi mejor escudo heráldico,-solía exclamar Augusto, refiriéndose a ella.

Y como tal, lo exhibía en las ocasiones memorables. Sus viejos amigos recordarán, sin duda, aquellas sesiones del Ateneo en que Augusto llegaba a la desbordante sala-teatro de la Universidad, dando el brazo a una viejecita menuda, de rostro fino y alargado, de tez blanquísima, aunque no tanto como los cabellos albos, aplastados bajo la capota sencilla. La fisonomía era como la expresión misma de la dulzura y de la bondad. Dos pedacitos de cielo azul asomaban por aquel marco de plata ennoblecido por la pátina de los años.

En el hemiciclo desbordante, aquel mozo alto y esbelto, de testa byroniana, sirviendo de báculo a esa viejecita de aspecto distinguido, constituía un cuadro que provocaba respetuoso y admirativo silencio, seguido de un murmullo aprobador. Y luego, en el momento en que el novelista era llamado para ocupar la tribuna, erguíase un instante en medio de la expectación general, depositaba un beso en la frente de la abuela, y subía las gradas con airosos movimientos de doncel trovador.

Los estudiantes rebullían en las tribunas altas. Las damas enfocaban sus ojos, afiebrados de ocultas ansias. La atmósfera caldeada de murmullos y de perfumes, latía como un corazón estimulado por el deseo. $\mathrm{Y}$ en ese momento, grave y pura, desgranábase la 
voz evocadora, como tejido de magia, dibujando imágenes airosas y trenzando esbeltas visiones en el ambiente propicio.

No tardaban en quebrar el silencio aplausos unánimes, que, en el trascurso de la lectura, iban creciendo como marejada impetuosa, hasta convertirse en ovaciones delirantes, en clamoreo que palpitaba como fogata enloquecida.

El héroe del momento bajaba de la tribuna con lentitud, pero sin jactancia, despreocupado y elegante como un príncipe quimérico, ofrecía el brazo a su viejecita y salía de la sala dignamente, saludando al pasar con fina sonrisa cordial.

Los estudiantes formábanle calle en el atrio y seguíanlo con gritos triunfales: «iViva el Zola chileno!»... «iViva nuestro Dostoiewsky!. . .» «iViva el Loti!. . » «iViva el Daudet!... »

En verdad, nadie concluía de ponerse de acuerdo sobre el parecido de ciertos astros de la literatura con aquel espíritu, multiforme y cambiante como espejo de agua movediza.

Y así se explica que este escritor adolescente haya podido ejercer una especie de dictadura espiritual sobre la juventud literaria de su época. Escritores ya maduros, o poetas noveles, lo agasajaban y respetaban. Alrededor de la revista Instantáneas que editaba Alfredo Melossi y que Thomson dirigía, fluía un continuo tumulto de admiraciones y de aplausos sinceros. Magallanes Moure, Samuel y Baldomero Lillo, Labarca Hubertson, Leonardo Pena, Dublé Urrutia, Valentín Brandau, Luis Ross, Carlos Pezoa Veliz, Víctor D. Silva, y tantos otros, formábanle círculo entusiasta, y, sí no lo reconocían todos como jefe, al menos lo respetaban como un árbitro del buen gusto y camarada indispensable en la orquestación de la literatura chilena. Tenía 20 años en aquella época. Y no sólo asumía la delantera en el lote literario; 
también los pintores y músicos le reconocían dérecho para dictaminar en obras de su especialidàd Ŕtafael Correa, Juan Francisco González, Valenzuela Llanos, Pedro Lira y algunos más que figuraban ya entre los venerables, lo acogían en su cónclave y admitían sus juicios con respeto.

Se comprenderá, entonces, la admiración casi fanática que debió despertar Augusto Thomson en la imaginación de un estudiante de diez y ocho años, en quien comenzaba a prender el virus del arte.

Cuando penetré por primera vez en el santuario del escritor, temblaba como un adolescente católico al aproximarse a la Divina Mesa. En la calle Libertad, muy próxima a la Plaza de Yungay, había una modesta casita de gruesos muros antiguos que se erguía entre sus vecinas como una señora de buena familia que sobrellevara su pobreza con dignidad. Allí vivía el novelista con su abuela y sus dos hermanas.

Augusto Thomson ha sido uno de los pocos escritores que en Chile ejerció su profesión como se entiende en Europa: con exclusividad. Por lo menos en su juventud, dedicó todo su tiempo a las letras. Las hemanas cuidaban de la casa. Augusto escribía con entera independencia, sin obligaciones de oficina $y$ sin grandes preocupaciones por el diario sustento. Las clases de música de la abuela bastaban para mantener una decorosa parvedad.

Cuando se golpeaba con el pesado aldabón en la casa de la calle Libertad asomaban por el ancho zaguán, las cabezas de dos niñas con aspecto de jóvenes misses. En la mañana, la consigna era implacable. El escritor no recibía; hallábase dedicado a sus elucubraciones literarias. Por las tardes, en cambio, se abría el amplio salón que servía a la vez de taller, y los amigos podían acercarse al altar y a su sacerdote. Augusto presidía las tertulias con lenta desenvoltura; sabía ser cordial sin descender a la plebeya 
camaradería; mantenerse a una distancia exenta de estiramiento; pontificar sin disminuir demasiado al neófito. De vez en cuando, si una nota de mal gusto se introducía en la reunión, con demasiada imprudencia, no tardaba en aparecer en sus labios una sonrisa irónica, seguida de una frase que desconcertaba al temerario $A$ menudo tomaba un libro, siempre de autor desconocido a la reunión, y leía con voz clara, austera y musical. Se dijera un joven griego elegante ejerciendo su apostolado en la clara intimidad de un hogar ateniense.

Se hablaba de Gorky, de Tolstoy y Dostoiewsky, los santos del día. Ibsen, Maeterlink y Haupmann, formaban el triunvirato de los dramaturgos.

Desde las amplias paredes de la sala, cubiertas de cuadros chilenos, de grabados y curiosidades artísticas, miraban con sus ojos inmóviles de retrato, los rostros venerables de artistas del arte contemporáneo: Zola, Daudet, Maupassant, Reclus, Krotpokin. Thomson poseía el arte de convertir su sala de trabajo en una especie de museo rancio y lleno de colorido. Audaces armonizaciones de Juan Francisco González, una gallarda cabecita del pintor Molina, saudosos paisajes de Valenzuela Llanos, bosquejos de Valenzuela Puelma, alguna miniatura escultórica de Simón González, formaban un conjunto que pesaba sobre los circunstantes como un baño de colores acariciadores, estimulando y tonificando los nervios apáticos.

Puestas en discusión las teorías de Tolstoy que en aquella época constituían novedad, se hablaba con veneración del artista de Yasnaia Poliana y de slis extrañas actuaciones de apóstol. Yo escuchaba con el espíritu abierto, recogido en mí mismo, vibrante, con deseos de intervenir en la conversación y, al mismo tiempo, poseído de angustiosa timidez. En verdad, reconocía en $\mathrm{mi}$ fuero interno que nadie dominaba aquel tema con mayor amplitud que yo. Tolstoy me 
era familiar hasta en sus menores detalles. Había estudiado sus novelas con escrupuloso cariño; sus teorías morales y filosóficas eran para mí tan conocidas como el silabario. Proyectaba presentar a la Academia que habíamos fundado en el Instituto Pedagógico, un estudio completo sobre el gran espíritu que llenaba el mundo con su renombre. Sin embargo, sintiéndome desconocido y apocado en aquel ambiente de intelectuales, entre los que me introducía subrepticiamente, mis conocimientos piafaban como un caballo contenido por duro freno.

Uno de los circunstantes más asiduos a las tertulias en casa de Augusto, y también uno de los más religiosamente entusiastas en su admiración por Tolstoy, era un joven con aspecto de luchador campesino, recio y cuadrado como un herrero, de claros ojos que, al sonreír, brillaban como un líquido entre los párpados estirados por una contracción de las sólidas mandíbulas. Alguien pronunció su nombre sonoro y arcaico:

- Julio Ortiz de Zárate.

Simpaticé desde el primer instante con su aspecto tranquilo, con su traje modesto y limpio, con sus gruesos zapatos de explorador. En aquella reunión de hombres marchitos por las ideas y el estudio, un poco librescos y amanerados, era como una ráfaga venida de esos campos cordilleranos en que crecen quiscos y se perfuman de toronja y yerba buena.

Me pareció que Ortiz de Zárate era quien más armonizaba con mi veneración por el maestro de Yasnaia Poliana y, seguramente estimulado por su presencia, me atreví a murmurar, con la voz apagada por la emoción:

- Tolstoy es nuestro padre... Yo iré pronto en peregrinación hasta Rusia, sólo para besar sus manos venerables...

Un silencio penoso acogió esta declaración de misticismo apasionado. Sin duda los circunstantes tilda- 
ron de exageración palabras que no eran sino un pálido reflejo de un espíritu vehemente, impulsivo y ardoroso. Sólo en Ortiz de Zárate encontré una mirada de comprensión simpática. Augusto fijó un instante sus ojos en mi persona y yo sentí la impresión de que el grande hombre me veía por primera vez. Luego, después de ensombrecer la frente con un pliegue reflexivo, habló bruscamente de otros asuntos.

Creía yo que mi persona azorada había vuelto de nuevo a su círculo de sombra y que ya nadie pensaba en sacarla a luz, cuando, en el momento en que nos despedíamos de Thomson, este dejó caer las siguientespalabras, erguido y un poco displicente:

Venga usted a reunirse conmigo esta tarde. Todos los días voy al Parque Forestal para despedir al sol que se va...

Era uno de los ritos de Augusto Thomson. También supe después que se convidaba todos los años con don Juan Mateo Gatica para saludar la primavera en Nuñoa, el día en que el vasto campo de durazneros y de almendros se cubre con su manto fastuoso, tejido de palidez y de rubor...

Eran actitudes que lo rodeaban de una atmósfera única, irreal y sugerente, embelleciendo con una nota romántiça hechos que la mayoría de las gentes suelen realizar en forma opaca y sencilla.

Naturalmente, acudí a la cita con devoción de peregrino. El Parque Forestal era entonces un paseo en formación; no existía el Palacio de Bellas Artes. En cambio, el horizonte se ampliaba, hacia el poniente en forma desmesurada y aparecía un panorama que, a nosotros, se nos antojaba oriental, quizás debido a una palmera que se erguía en el extremo del paseo y de unas cúpulas de iglesias o edificios que daban una remota impresión de iglesias ortodojas.

Augusto tejía, a propósito del crepúsculo, una leyenda fantástica. Solía recitar a media voź algún ver- 
so sugerente, con la cabeza descubierta, los lejanos ojos perdidos en vaguedades infinitas. Pero aquellas expansiones que en cualquier otro hubieran parecido amaneradas, eran en él como la prolongación de su figura naturalmente elegante. El tono sobrio de su voz, la esbeltez de su cuerpo, la gracia austera de su gesto, asemejábanlo, en ese instante, más a un joven fakir que a un poeta desorbitado.

Durante estos encuentros que se repitieron, íbamos siempre quedando solos Augusto Thomson, Ortiz de Zárate y yo; en esos instantes, como una obsesión, iba a caer nuestra charla sobre el tema de Tolstoy, sobre la belleza de la vida sencilla, de la irresistencia al mal, del apostolado educativo que se podría ejercer entre los campesinos y de la necesidad de huir de los viciosos placeres de la vida ciudadana.

Al cabo de repetir muchas veces parecidas ideas, confieso que comenzaron a fatigarme $y$, un día, sacando bríos de timidez, me atreví a alzar secamente la voz ante el joven maestro:

Y si tanto les agrada la vida tolstoyana, ¿por qué no la realizan? ¿Hay algún obstáculo que les impida vivir de acuerdo con sus ideas?

Mis interlocutores quedaron un instante en silencio. No puedo asegurar cual fué el efecto producido por mis palabras. Para mí la complejidad del mundo se me aparecía fácil y clara; el camino por recorrer tan acogedor, tañ suave, como el horizonte inundado por los reflejos del sol muriente que teníamos a la vista, y mi espíritu inexperto vagaba por regiones lejanas como un brioso bajel incontenible.

Al regresar esa tarde, a la hora en que se encendían los primeros faroles, nuestros pasos resonaron con mayor gravedad por las calles desiertas. Discutíamos sobre la posibilidad de llevar a la práctica el proyecto de fundar una colonia tolstoyana...

Santiago, 1933. 